\title{
Barriers to energy sustainability: A case study from Ukraine
}

\author{
Anatoliy Goncharuk ${ }^{1,}{ }^{*}$, Veronika Khudolei $^{2}$, Olena Stanislavyk ${ }^{3}$, Vadym Yatsyshyn ${ }^{1}$, \\ and Yuliia Semenchuk ${ }^{1}$ \\ ${ }^{1}$ International Humanitarian University, Odessa, Ukraine \\ ${ }^{2}$ Academician Yuriy Bugay International Scientific and Technical University, Kyiv, Ukraine \\ ${ }^{3}$ Odessa Polytechnic State University, Odessa, Ukraine
}

\begin{abstract}
Sustainability goals imply not only economic and environmental components, but also a social one. The energy business around the world is profitable and economically viable, but it does not always bring appropriate benefits to a society. Besides, some governments, instead of protecting the interests of the population, turn a blind eye and generate injustice in relation to some parts of society in collaboration with energy companies. This paper examines one of the cases when the authorities pursue an unfair policy and contribute to the growth of inequality in society through regulating the natural gas tariffs. The paper considers a case of natural gas consumption and its unfair taxation by the Ukrainian government, which the authors called "gas tax". A statistical analysis of this case revealed that honest middle-income taxpayers (middle class) are at the most disadvantageous position because they have to pay for utilities at the highest price. The paper also discusses a number of challenges and ethical issues related to the payment of gas tax. All these challenges should become arguments for revising the gas tax, making it less painful for the people and fair.
\end{abstract}

Keywords: barriers, energy sustainability, Ukraine

\section{Introduction}

Achieving energy sustainability goals implies ensuring the economic, environmental and social efficiency of the energy sector. However, in all countries there is some kind of opposition: consumers, including the households, intend to receive enough energy at lower prices; however, suppliers, including energy companies, strive to sell energy at higher prices. The government usually regulates the energy market. Hence, the price of energy sold in a particular market often depends on the policy of the regulator. The government gives sufficient access to energy for all the consumers if it intends to reduce energy poverty [1] and to increase the energy consumption [2]. However, while regulating the energy market, the government can intend to achieve other goals, e.g., financial, economic, political, or even

* Corresponding author: $\underline{\operatorname{agg} @ \text { ua.fm }}$ 
fiscal. Among energy sources, natural gas seems to be the most politicized. That is why it is the subject of this paper.

In recent decades, politicians have actively used natural gas as a tool of economic and political pressure. Originally coming from a lexicon of chemical warfare, currently the term "gas war" is actively applied in everyday life and literature in its indirect sense. The most known cases of recent "gas wars" were Russia in 2014 [3] and Bolivia in 2003 [4]. As a rule, natural gas is used in such wars as a tool of international pressure to obtain economic and political concessions.

However, in recent years natural gas has been used as a tool of fiscal or financial pressure. This assumes an introduction of new taxation tool: an increase of natural gas prices for various consumers. It was tested by the government of Ukraine during the implementation of the cooperation program signed with IMF (International Monetary Fund). In the context of a huge shadow economy that exists in Ukraine, the traditional taxation tools weaken an impact on public finances. With a low tax base, raising traditional taxes does not translate into a corresponding increase in tax revenue. At the same time, considering a high external debt of Ukraine, this country needs new borrowings to avoid default. So, it was agreed that the IMF provides new 3.9 billion USD tranche for Ukraine during the further 14 months [5]. But one of the key conditions for that was a substantial 60 percent increase of natural gas price for households.

In response, the Ukrainian government provided raising a natural gas price up to 305 USD (by 23.5\%) per thousand cubic meters for the households starting from the last two month of 2018 [6]. In 2019, the growth of this price for households continued [5]. Yulia Tymoshenko, the former head of the Ukrainian government, called this growth a "crime" and "genocide against the Ukrainian people", warning that "most families simply will not survive the winter" with the natural gas at increased prices [7]. Hence, the point is: was such the rise in natural gas prices so tragic for households? Is it equally painful for all the groups of households? This study will attempt to answer these questions from a financial point of view.

\section{Literature Review}

As it was recently found [8], the efficiency of operators working in the Ukrainian gas sector is low, so there is an opportunity to develop more efficient market configurations. Moreover, among the critical issues for developing an effective policy in the gas market, it was proposed "while greater efficiency is necessary to reduce cost and increase service quality, at different stages of progress of the reform process other goals may be more important" [8, p. 464]. Hence, it seems that it is the fiscal goals that dominate the Ukrainian gas market now.

Taking into account the relevant literature, several publications have been identified that more or less relate to the challenge under consideration including two main aspects. The first of them considers the problem of a significant rise in the price of natural gas that can be viewed as an increase in energy poverty of the country, expressed in the less availability of that for households. Buzarowski and Tirado Herrero [9] viewed the energy poverty as the inability of the households to provide the socially and financially necessary amount of energy services at their houses. Bollino and Botti [10] developed a synthetic indicator for measuring energy poverty to estimate households' well-being in various areas of their energy inequality. However, they focused on energy availability and thermal efficiency without considering a natural gas specially. A study on Croatia [11] found that energy poverty in this country became a very burning problem, to which natural gas made a significant contribution (about $28 \%)$.

Therefore, rising prices of natural gas to some level exacerbate energy poverty that defines the possibilities of households to get enough energies for their life. Sometimes, this may provide gas savings for households (take, for instance, a case of a $4 \%$ economy of natural 
gas for house boilers in Poland) [12]. But mainly rising energy prices lead to an increase in annual energy costs for European households in almost all Member States, with significant differences between countries and even within them [13].

On the other hand, rising natural gas prices may exacerbate social inequality. Thus, Preotezi [14] found that in Romania rising natural gas prices had a strong impact on the budgets of poor households, exacerbating social inequality. However, effective government subsidy policies for poor households could neutralize this negative effect. A number of countries provide such subsidies, Ukraine being one of them. At the same time, in this country, subsidies from the government are directed to regional distribution companies, which are owned by oligarchs, through their retail subsidiaries known as "gazzbut" (gas sales), rather than directly to consumers [15].

In addition, it is necessary to make special mention of a number of international studies [16-68], which consider the issues of development management at various scales of economic activity in the context of forming a system of factors affecting the energy policy of the state, both in particular and in general.

However, the Cabinet of Ministers of Ukraine announced the redirection of subsidies from gas selling retailers to households from the end of 2017. So, are those subsidies fair? Unfortunately, the literature does not provide answers to this question. Thus, this paper aims to figure out how such the Ukrainian government policy on natural gas reflects the revenues and expenditures of the key stakeholders: gas market operators and domestic households.

\section{Method}

This study uses theoretical and empirical methods to define the influence of the current Ukrainian state policy for regulating natural gas prices on the households. Among other things, the following methods and tools were applied in this study:

- indicators of distributions, in particular, the distribution of people by monthly income per capita;

- dynamics indicators, e.g., profitability growth rate (annual) as a percentage;

- structure indicators, e.g., share of utility rates;

- as well as the other indicators for study goals.

The order of research methodology is disclosed at the Fig. 1.
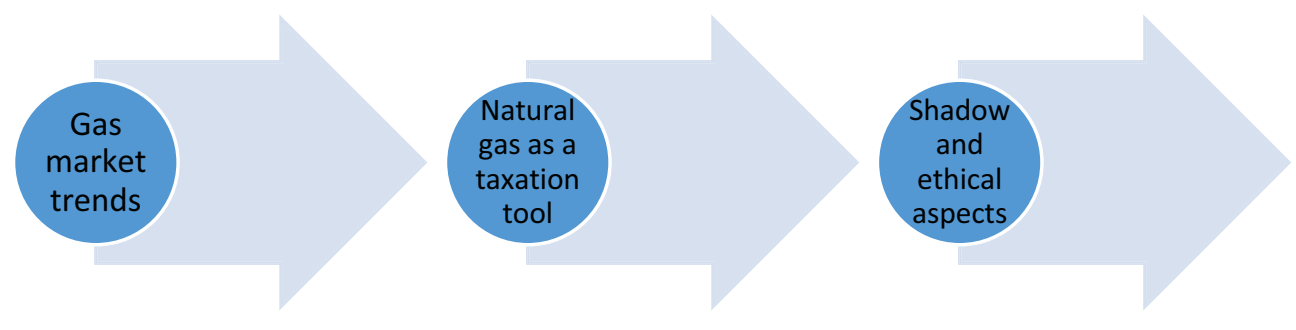

Fig. 1. Research methodology.

First, the profitability of gas companies is defined in a result of changes in the government's pricing policy, as well as the trends in the natural gas market are determined. Second, the new policy is analysed and viewed as a gas tax for households, that is, a fiscal tool. And at the end, the fairness of gas tax will be examined in cases, considering its shadow and ethical aspects. 


\section{Results and Discussions}

\subsection{Gas Market Trends}

Natural gas is a key energy resource in the economy of Ukraine. Industrial needs for natural gas there is much higher than its own extraction. However, it is enough for the consumption of households and communal services. Until 2014, Ukraine covered its domestic natural gas deficit by importing Russian gas. But in 2014, after the beginning of the real war with Russia, Ukraine refused Russian gas and started importing natural gas from the EU.

Explicit households' subsidies, due to low heating and gas tariffs, for households have been the preferred policy in Ukraine. But with time, they were becoming more expensive. And according to IMF experts [16], low tariffs support low-income households while favouring those who consume a lot, usually rich households.

Therefore, the IMF asked to increase gas prices for consumers by $280 \%$ and heating - by $66 \%$ as a condition for additional financial assistance. This was done quickly by the government of Ukraine. Ukraine's budget revenues was low due to a sharp decline in GDP (in 2014-15: by 15.6\%), growing expenditures on army (in 2016: up to 7.1\% of the total state expenditures), and external debt payments (in 2017: reached $30.3 \%$ of the total state expenditures). Thus, having agreement with the IMF, the government of Ukraine increased its fiscal pressure on households through increasing the price of natural gas. It was supplied by the Naftohaz Ukrainy (NHU) - the state-owned monopoly company. All the households, industries and other organisations bought natural gas from the NHU through the local gas distribution companies (GDCs). Figure 2 shows the changes in operating profitability of GDCs and NHU.

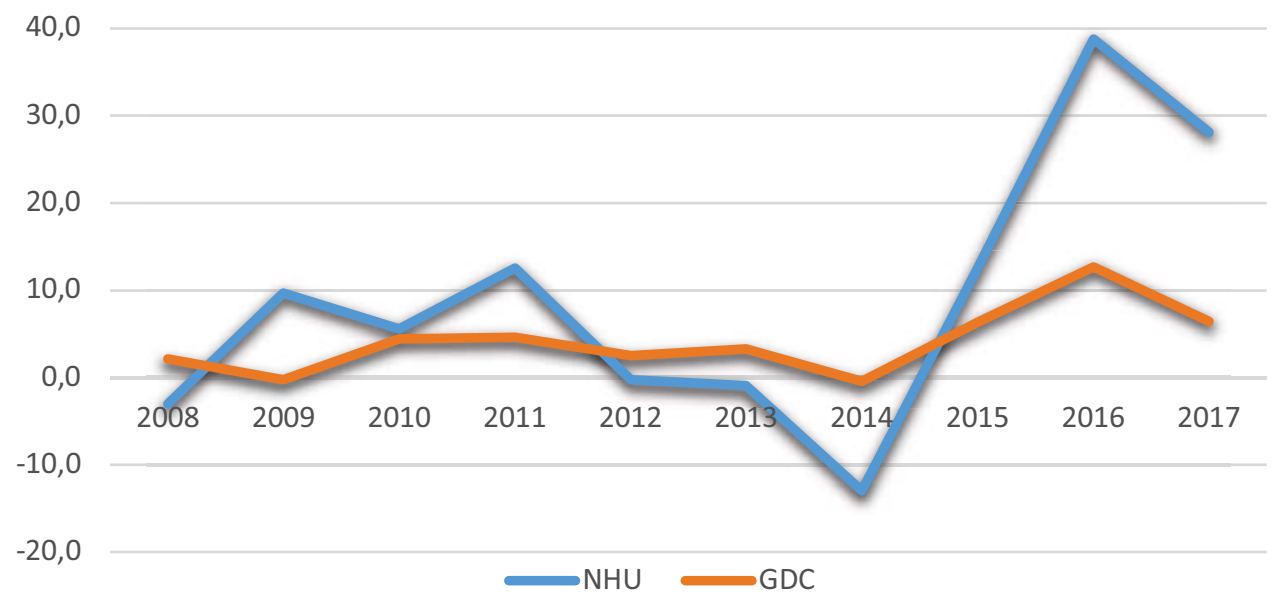

Fig. 2. Profitability of operating activities of NHU and regional GDCs, $\%$.

Source: Calculated by the authors based on SMIDA data [18].

Since a sharp rise in gas prices (2015-2017) the NHU has become highly profitable. For three years its net sales grew 2.5 times up to 6.25 billion euros. So, in 2017 its net income reached 1.3 billion euros. It is excessive financial results for a company with only 700 employees. The resulting excess income was spent on paying huge bonuses to the top management of NHU and channelled to the state budget. GDCs also used their surplus to pay taxes. 


\subsection{Natural Gas as a Taxation Tool}

Calculations based on data from the State Statistics Service of Ukraine [19] showed that the new gas tax in 2017 alone brought about 2 billion euros to the state budget, i.e., about $8 \%$ of all budget revenues. Hence, this new tax takes a fourth position among the traditional Ukrainian taxes, yielding only to VAT (50\%), income tax (11\%), and excise tax (9\%).

In an attempt to find out how fair the gas tax is, it was found that almost all Ukrainian households depend on natural gas. Most of them use gas for cooking as well as heating. Since the climate in Ukraine is very cold, heating is used here 6 months a year, and therefore gas consumption is very high.

Moreover, being one of the poorest European countries [20], Ukraine had in 2016 above 58 per cent of citizens below the poverty line [21]. The comparison of the Ukrainian level of material deprivation (42\%) and deep one (27\%) [74] with the level of 28 EU countries (16\% and $8 \%$ ) [22] shows that it is 2-3 times higher.

The quick growth in prices for natural gas led to an almost double increase in the average share of utility costs in the structure of total household expenditures, which increased from $8.1 \%$ in 2014 to $15.4 \%$ in 2017 [21]. To understand whether this growth was uniform and fair for all groups of the population, the subsidy calculator was applied [23]. It showed that a Ukrainian household could receive a partial subsidy in 2018 if its average monthly income did not exceed 244 euros. To realize how appropriate this amount was it was compared with an average salary in Ukraine, which in September 2018 was $14 \%$ higher than this level of subsidy [21]. Given that only 7.6 million people out of Ukraine's 42 million people are officially employed, it can be assumed that the average income per capita is much lower than the average salary. Indeed, if the average household income in 2017 is taken into account, it was only UAH 8,165 for the average population of 2.58 households [21]. Thus, the monthly income per capita in Ukraine in 2017 was 105 euros. This means that the majority of the population of Ukraine should have received a financial aid from the state in the form of subsidies for utilities.

Nowadays, only a few sectors in Ukraine pay official salaries above the average level. They include financial business, transport, IT, telecommunications, public administration, professional, scientific, and technical activities [21]. According to the Ukrainian standards, workers in these sectors can be considered as a middle class with monthly earning from 300 up to 1,000 euros. So, later in this study, the households with monthly earnings over 170 euros per capita will be considered as middle-class households. Since introduction of the gas tax for households, the level of income inequality in Ukraine has changed tragically (Fig. 3).

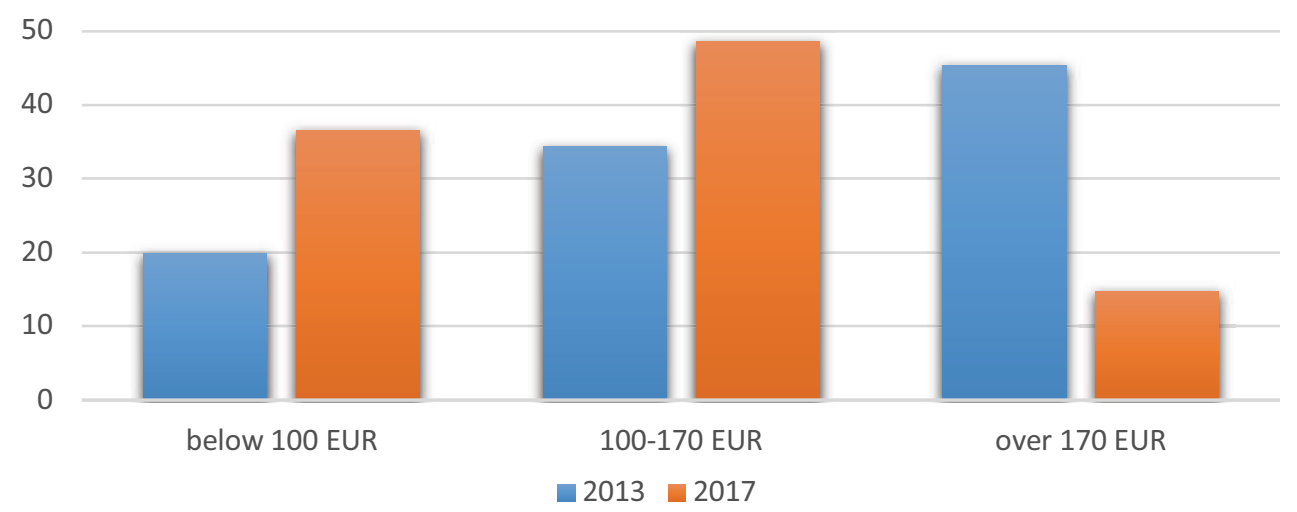

Fig. 3. Distribution of the Ukrainian monthly income per capita in 2013 and 2017, euros.

Source: Ukrstat [21]. 
Back in 2013, the share of the middle and wealthy class accounted for $45.4 \%$, but by the beginning of 2018, due to increased tax pressure and the economic crisis, it already fell to $14.8 \%$. As a result, budget revenues, including the new gas tax, rose to $35 \%$ of GDP.

\subsection{A Case of the "Gas Tax"}

The main burden of this gas tax fell on the middle class, as these amounts are not significant for rich people, and poor people received subsidies. The results can be seen in Fig. 4 and 5 in the case of families with four different incomes and other things being equal: the utility rate of $€ 80$ per $50 \mathrm{~m} 2$ apartments for a double household.

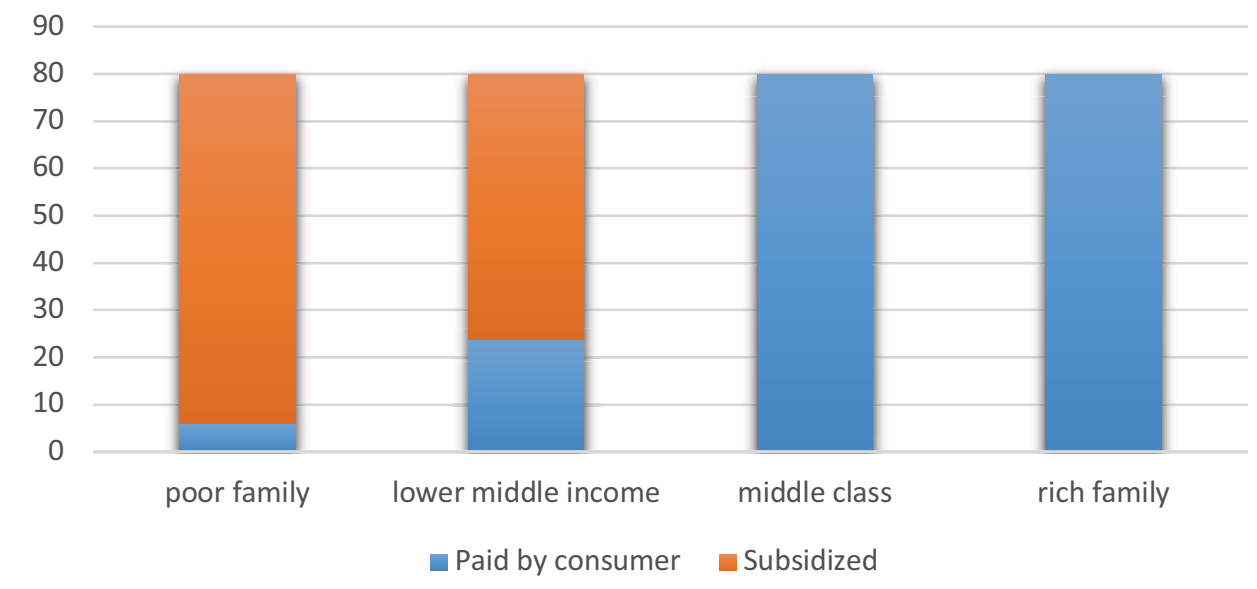

Fig. 4. Four cases of the structure of utility tariffs for the same apartments, euros.

Source: Ukrstat [23].

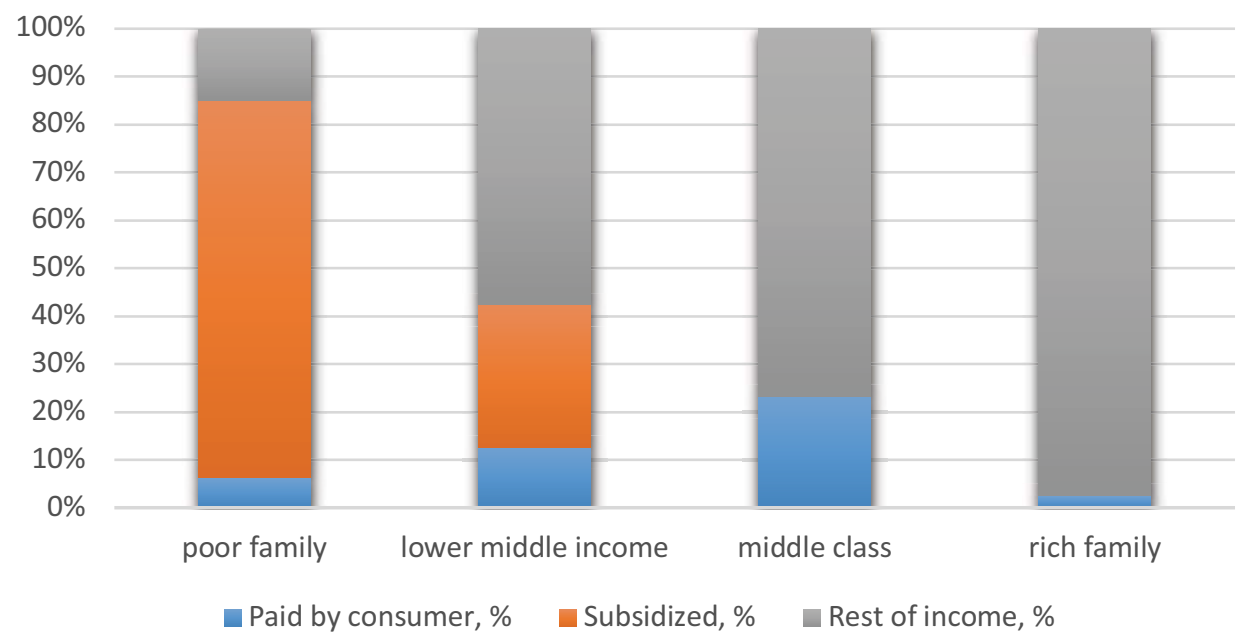

Fig. 5. Four cases of the share of utility bills in the monthly household income, $\%$.

Source: Ukrstat [23]. 
Currently, only less than $15 \%$ of domestic households actually pay for most of the utilities consumed by all households. Moreover, the middle-class households pay most of this gas tax as a percentage of the household's monthly income (over 23\%), but in the same amount as in an achievable family, which is less than $3 \%$ of its monthly income. All of this shows the injustice that is generated by the new gas tax, in which the middle class pays the highest price, and the poor and rich find themselves in the most advantageous position, paying an insignificant part of their income for communal services. In such a system, incentives for poor households to earn more are lost because they may then lose the subsidy. Such a tax indicates a clear injustice in relation to the middle class, which is the key to the stability of any democratic country.

\section{4 "Shadow" and Ethical Aspects of the "Gas Tax"}

This research tried to find out if the supporters of the gas tax are right, arguing that it helps to legalize shadow income and reduce the shadow economy.

As shown by Schneider and Medina [24], the average shadow economy index for Ukraine in 2015 was $43 \%$, which is almost 2 times higher than the average for 158 countries $(28.7 \%)$. This means that almost half of the Ukrainian economy does not pay taxes and is hidden from the state. Tax and institutional pressures, including corruption and bad justice, are often cited as key causes of the shadow economy $[25,26]$. Hence, the gas tax should strengthen the shadow economy, and the government's actions are only aimed at solving the current financial problems at the expense of the middle class. However, this method has a number of disadvantages, among which the following can be distinguished:

- The cost inflation growth. Ukrainian economy has a high dependence on a natural gas that is used as a raw material (in chemical industry), technological resource (metallurgy), for heating and consumption. So, it makes this economy highly sensitive to natural gas price changes [27].

- Lower consumption. Increasing gas price leads to higher cost of utilities and hence to a decreasing households' consumption.

- Lower business profitability. As natural gas is a critical energy resource, its price impacts a cost of production and utility cost. Some crucial industrial enterprises (chemical, metallurgical) cannot pay so high price for natural gas and get losses [28]. At the same time, higher gas prices lead to lower consumption of households that shorten sales of many consumer services and goods.

- Increasing inequality of society and reducing the middle class. This trend is shown in Fig. 3. It leads to the society's degradation to lumpens and increased tensions.

- Growth of the shadow economy and concealment of real incomes. When households receive a utility subsidy because of low income, it encourages them to hide their actual income to save more money on living. In a corrupted system with low institutional quality, this counter-argument may, as the government expects, cancel attempts to fill the budget with household shadow income.

The ethical aspect of the gas tax is also a very important challenge here [29, 30]. It is expressed in the fact that only honest people who work in the legal sector of the economy pay taxes. Moreover, in Ukraine they pay both for themselves and for those who hide their income from the state and claim a gas tax subsidy. The corrupt system of state fiscal control existing in the country cannot identify and punish the latter. Therefore, they feel comfortable and, in fact, benefit from the new gas tax. In contrast, honest taxpayers are forced to restrict consumption due to rising taxes. Hence, injustice arises when households with the same living conditions, income and housing pay different taxes only because they have different morals and values, and work in different sectors of the economy (legal and shadow). 
Dishonest people win in such a system, while honest ones are forced to pay for themselves and others and limit themselves in vital expenses. Many honest people in such conditions decide to leave their country and seek justice and decent income abroad, they migrate to the EU countries, fleeing from injustice and hard life.

\section{Conclusion}

All mistakes must be corrected sooner or later, otherwise they can turn into a disaster. In 2014, only the IMF extended a helping hand to the Ukrainian government, which was trying to save the country's economy from default in the face of recession and war with Russia. However, those resources turned out to be insufficient and the corrupt system consumed more and more resources. As a result, for the next tranche of the IMF, the Ukrainian authorities decided to sacrifice the middle class, increasing the pressure on honest taxpayers by introducing a new tax. This tax has benefited the poorest and richest households. We called it the "gas tax". It was introduced four years ago by raising the price of gas and heating for households with the introduction of utility subsidies for the poorest households.

However, the Ukrainian government did not believe that consumers could also be dishonest in a corrupt system. As a result, the number of households in need of utility subsidies increased from 29\% in 2016 to $46 \%$ in 2017. Currently, more than half of all Ukrainian households receive utility subsidies. It turns out that honest taxpayers who receive average income (middle class) are at a disadvantage because they are forced to pay the highest price and the largest share of their income for utilities. Moreover, according to a recent study, [31], during the COVID-19 pandemic in 2020, the problem of energy poverty in Ukraine became even more acute.

This study identified a number of barriers to energy sustainability, including challenges and ethical issues that arose during the application of the gas tax in Ukraine. Among them the following are obvious: rising cost inflation; reduction of domestic consumption; the decreased profitability of domestic business; reduction of the middle class and increase in the society stratification; concealment of real incomes and growth of the shadow economy; increasing injustice and labour migration abroad. All of these issues are arguments for revising a new taxation tool called the gas tax to make it fairer and less painful for the economy and households.

\section{References}

1. S. Bouzarovski. Wiley Interdisciplinary Reviews: Energy and Environment, 3, 3, 276-289 (2014).

2. S. Thomas, J. Rosenow. Energy Policy, 111108 (2019).

3. M. Pigliucci. Advances in Economics and Business, 4(3), 124-131 (2016).

4. T. Perreault. Natural gas, indigenous mobilization and the Bolivian state, Identities, Conflict and Cohesion Programme Paper, No. 12, July 2008, United Nations Research Institute for Social Development, Geneva (2008).

5. J. Murphy (2018), NewsBase, 42, 1004, 24 October (2018).

6. Resolution of the Cabinet of Ministers of Ukraine "On Approval of the Provision on the Imposition of Special Responsibilities on the Natural Gas Market Actors for Provision of General Public Interests in the Process of Operation of the Natural Gas Market”, 867 dated 19.10.2018, Legislation of Ukraine (2018).

7. Y. Tymoshenko, The gas tariff increase is a crime against one's own people, Official site by Yulia Tymoshenko, 20.10.2018, (2018).

8. A.G. Goncharuk, C. lo Storto. Energy Policy, 101, February, 456-466 (2017). 
9. S. Bouzarovski, S. Tirado Herrero. European Urban and Regional Studies, 24 (1), 69-86 (2017).

10. C.A. Bollino, F. Botti. PSL Quarterly Review, 70 (283), pp. $473-507$ (2018).

11. N.V. Lenz, I. Grgurev, Energy poverty in Croatia: New Insights, Proceedings of the 7th MAC 2016, 201-208 (2016).

12. D.A. Krawczyk. Energy Procedia, 95, September, 216-222 (2016).

13. K. Grave, B. Breitschopf, J. Ordonez, J. Wachsmuth, S. Boeve, M. Smith, M. Pudlik. Prices and costs of EU energy, Final Report, European Commission, ECOFYS Netherlands B.V. (2016).

14. M. Preotesi. Revista de Cercetare şi Intervenţie Socială, 55, 139-157 (2016).

15. S. Saha, I. Zaslavskiy. Advancing Natural Gas Reform in Ukraine, Discussion Paper, December, Council on Foreign Relations, New York (2018).

16. P. Mitra, R. Atoyan. Ukraine Gas Pricing Policy: Distributional Consequences of Tariff Increases, IMF Working Paper, WP/12/247, October 2012, European Department, International Monetary Fund, (2012).

17. R. Duvignau. Business News, 20 Feb, 2015.

18. Companies' reporting, Stock market infrastructure development agency of Ukraine, SMIDA (2021).

19. Budget 2017 implementation, State Treasury Service of Ukraine, SSSU (2021).

20. Poorest Countries in Europe 2021, World Population Review (2021).

21. Annual Statistics, State Statistic Service of Ukraine, Kyiv, Ukrstat (2021).

22. European Statistics, European Commission, Eurostat (2021).

23. Utility and subsidy calculator, Government hotline, Teplo (2021).

24. F. Schneider, L. Medina. Shadow economies around the world: New results for 158 countries over 1991-2015, Working Paper, 1710, Johannes Kepler University of Linz, Department of Economics, Linz (2017).

25. G. Kirchgässner. German Economic Review, 18 (1), 99-111, (2017).

26. A. Buehn, R. Dell'Anno, F. Schneider. Empirical Economics, 54 (4), 1609-1630 (2018).

27. A.G. Goncharuk. International Journal of Energy Sector Management, 7 (4), 448-458 (2013).

28. A.G. Goncharuk. International Journal of Energy Sector Management, 9 (1), 94-104 (2015).

29. A. Goncharuk, A. Figurek, V. Truba, I. Nyenno. Problems and Perspectives in Management, 17 (4), 360-369 (2019).

30. A.G. Goncharuk, G.T. Cirella. The Extractive Industries and Society, 7 (2), 587-592 (2020).

31. A.G. Goncharuk, K. Hromovenko, A. Pahlevanzade, Y. Hrinchenko. Polityka Energetyczna, 24 (2), 5-18 (2021). 